\title{
Research Square \\ One Health in The Brazilian Western Amazon: Helminths in Native Fish and The Food Change of The Puruborá People
}

\section{Mayra Araguaia Pereira Figueiredo}

Universidade Federal de Rondônia, Rolim de Moura - RO

\section{Gisele Oliveira Montanha}

Universidade Federal de Rondônia, Rolim de Moura - RO

Wilson Gómez Manrique ( $\nabla$ wilson.gomez@unir.br)

Universidade Federal de Rondônia, Rolim de Moura - RO

\section{Research Article}

Keywords: One Health, native fish, food

Posted Date: September 15th, 2021

DOI: https://doi.org/10.21203/rs.3.rs-871214/v1

License: (c) This work is licensed under a Creative Commons Attribution 4.0 International License.

Read Full License 


\title{
One Health in the Brazilian Western Amazon: helminths in native fish and the food change of the Puruborá people
}

Mayra Araguaia Pereira Figueiredo ${ }^{1}$ Gisele de Oliveira Montanha², Wilson Gómez Manrique $^{3 *}$

${ }^{1}$ Laboratório de Parasitologia, Entomologia e Biologia Molecular voltado à Saúde Única-LAPEMSU. Departamento de Medicina Veterinária e Programa de PósGraduação em Ciências Ambientais, Universidade Federal de Rondônia, Campus Rolim de Moura.

${ }^{2}$ Grupo de Pesquisa e Extensão em Sanidade Aquícola - GRUPESA, Laboratório de Sanidade Aquícola - LABSA. Departamento de Medicina Veterinária, Universidade Federal de Rondônia, Campus Rolim de Moura.

${ }^{3}$ Grupo de Pesquisa e Extensão em Sanidade Aquícola - GRUPESA, Laboratório de Sanidade Aquícola - LABSA. Departamento de Medicina Veterinária, Universidade Federal de Rondônia, Campus Rolim de Moura. Programa de Pós-graduação da Rede Bionorte. Av. Norte Sul, 7300 - Nova Morada, Rolim de Moura, CEP 76940-000. Rolim de Moura - RO, Brasil.

* Corresponding author: wilson.gomez@unir.br

All the authors contributed equally to this work

\begin{abstract}
The aim was to approach an analysis of fish parasites in the Manoel Correia and Caio Espínola Rivers, which border the Aldeia Aperoi, and the report of the Puruborá People on the use of fish as animal protein. Twenty-one fish were collected in the dry season and 15 in the rainy season, totaling 36 specimens, which dissipated cestodes, acanthocephala and nematodes encysted in the musculature, preventing their consumption. Six residents of Aldeia Aperoi were interviewed. The circulation of parasites with zoonotic potential was identified in fish native to the Manoel Correia and Caio Espínola rivers, which border the Aldeia Aperoi, in the Western Amazon of Brazil. It was verified the helplessness of the Puruborá people regarding their inquiries about the environmental imbalance, which causes the loss of fish diversity and, consequently, damage to their culture and their costumes.
\end{abstract}

\section{Introduction}


Foodborne diseases (FBD) are infections or intoxications caused by eating contaminated food and/or water that have an impact on public health ${ }^{1}$. There are more than 250 types of FDB, and among them, those caused by parasitic infections due to fish consumption $^{2,3}$.

The identification of parasitic diseases associated with the consumption of fish in Brazil is not easy, as most are not mandatory to report. Additionally, due to the low severity of the symptoms and the little knowledge by the doctors on the subject, they go unnoticed ${ }^{4}$. Thus, the most appropriate approach to parasitic diseases in fish is in the context of one health, since ecological studies on freshwater fish parasites provide relevant data on the seasonality and susceptibility of the parasites and their hosts, while analyze the health status of fish, streams and indigenous people who use this source of protein as food, in addition to the quality of the water. Thus, there are answers regarding the imbalance of the environment and the possibility of zoonoses due to the consumption of parasitic fish ${ }^{5}$.

Fish are, worldwide, an important protein source for thousands of people; however, for indigenous and riverine people it does not only represent the food and economic base, but also the maintenance of customs and culture ${ }^{6}$, especially for groups that settled on the banks of rivers, as occurs in the Amazon. The Puruborá People on the state of Rondônia in the Western Amazon of Brazil is such an example.

The history of colonization and occupation of the state of Rondônia (whichwas created only in 1981), located in the western Brazilian Amazon, is full of disorderly occupations and invasions of forest spaces and indigenous lands. This is the result of several economic cycles: rubber, wood and precious metals. In all cycles, the destruction or extinction of indigenous ethnic groups was observed ${ }^{7}$.

The Puruborá people had their first contact with non-indigenous people in 1909, and from that moment on they began deconstructing themselves as a people/ethnicity. They suffered great miscigenation with the rubber tappers who occupied the area during the rubber cycle. Thus, the Puruborá people were expelled from their lands, and expropriated from their language and culture and were almost decimated by diseases ${ }^{8}$. Over the years they spread throughout the territory of Rondônia and for survival, they became an ethnic group with mixed race with blacks, whites, other indigenous peoples, in addition to Bolivians and quilombolas ${ }^{8,9}$.

At the end of the 1990s the Puruborá were forced to start a new life on the banks of the BR-429, between the municipalities of Seringueiras and São Francisco do 
Guaporé, in Rondônia, which was later known as Aperoi Village ${ }^{10}$. Currently, the Puruborá People try to recover their identity, language and customs ${ }^{11}$.

However, the eating behavior based on fish protein has been modified due to environmental changes caused, among others, by damming and contamination of rivers, loss of ichthyofauna diversity and increase of parasites in fish. In relation to the latter, it is known that parasites can be bioindicators of environmental balance, since they present advantages over other organisms, such as rapid response to environmental changes, due to the interdependence of the ecological networks in which they live ${ }^{12}$. In Brazil, ethnichthyological studies under the view of health status with riverside and indigenous populations are scarce.

Thus, this study aimed to address the analysis of fish parasites in the Manoel Correia and Caio Espínola Rivers, which border the Aperoi Village and the Puruborá People's narratives on the use of fish as animal protein.

\section{Results}

\section{Identification of parasites}

In Aperoi Village fishing can be performed by men and women, and also by children, when accompanied by adults.

We identified in this work the following parasites: of the genus Eustrongylides sp., third-instar larvae of Contracaecum sp., metacercaria of Ithyoclinostomum sp. and Neoechinorhynchus buttnerae (Table 1).

Table 1. Prevalence, location and parasites identified in naturally infected native fish in the Manoel Correia and Caio Espínola rivers, municipality of Seringueiras, state of Rondônia, Brazil.

\begin{tabular}{|c|c|c|c|c|c|}
\hline Sample & $\begin{array}{l}\text { Scientific } \\
\text { name }\end{array}$ & $\begin{array}{l}\text { Common } \\
\text { name }\end{array}$ & Parasite & Tissue & $\mathbf{P}^{*}$ \\
\hline \multirow{3}{*}{$\mathrm{N}=16$} & \multirow{3}{*}{$\begin{array}{l}\text { Hoplerythrinus } \\
\text { sp. }\end{array}$} & \multirow{3}{*}{ Jeju } & Eustrongylides sp. & Skeletal muscle & 100 \\
\hline & & & $\begin{array}{l}\text { 3rd-instar larvae of Contracaecum } \\
\text { sp. }\end{array}$ & $\begin{array}{l}\text { Encysted in the } \\
\text { intestinal serosa }\end{array}$ & 18 \\
\hline & & & $\begin{array}{l}\text { Metacercaria of Ithyoclinostomum } \\
\text { sp. }\end{array}$ & Skeletal muscle & 6.25 \\
\hline $\mathrm{N}=17$ & Hoplias sp. & Traíra & Neoechinorhynchus buttnerae & Intestine & 35.29 \\
\hline
\end{tabular}




\begin{tabular}{|c|c|c|c|c|c|}
\hline & & & \multirow{2}{*}{$\begin{array}{l}\text { Eustrongylides sp. } \\
\text { 3rd-instar larvae of Contracaecum } \\
\text { sp. }\end{array}$} & Skeletal muscle & 100 \\
\hline & & & & $\begin{array}{l}\text { Stomach and } \\
\text { mesentery serosa }\end{array}$ & 41.17 \\
\hline & & & $\begin{array}{l}\text { metacercaria of Ithyoclinostomum } \\
\text { sp. }\end{array}$ & Skeletal muscle & 11.76 \\
\hline $\mathrm{N}=2$ & Cichla sp. & Tucunaré & Eustrongylides sp. & Skeletal muscle & 50 \\
\hline $\mathrm{N}=01$ & Pimelodus sp. & Mandim & - & - & 0 \\
\hline
\end{tabular}

$* \mathrm{P}-$ prevalence by fish species.

\section{Transcript of interviews with indigenous residents of Aperoi village}

We selected relevant excerpts regarding the dietary change in the use of fish protein in the past ten years in Aperoi Village. The researchers respected the way of speaking and the common name that the interviewees gave to objects and fish.

Researcher asked: Good morning! Could you please tell me how the fishes and the Manoel Correia and Caio Espínola rivers were like about ten years ago?

Interviewee 1: Regarding what we eat, we used a lot of fish. From about ten years ago our river has changed very much in the aspect of water volume - because before our river didn't get dry - so it was plenty of fish all the time and there wasn't a lot of fisherman. But then the number of fishermen increased and the river is now drying up. It is very harmful for the people who need this food, as we believe that some worms in fish are caused by the lack of water. When we catch and open the traíra it has worms. We normally take it out and consume it anyway, but when it has a lot of worms, we have to throw it away. The same thing is with the peacock bass, also with lots of worms during the dry season. But I don't know if it's because the water is still when the river is drying up, or if it's something that it uses as food. For example, we fish the pacu (Piaractus mesopotamicus) with longline (a heavy fishing line that may be many miles long and that has baited hooks in series) during the flood season, but it also comes with many worms. We don't know whether it is good or bad to eat these fish, but the river is a 
very essential source of food for us, the Puruborá, it is really important.

Researcher asked: Do you believe there has been a great decrease in fish populations in the Manoel Correia River? And if so, in which species did you notice the greatest decreases and presence of parasites?

Interviewee 2: The peacock bass, piau (Leporinus sp.), piranha (Pygocentrus sp.) and catfish had no worms, it was nice then.

interviewee 3: The fish that we used to catch a lot in this river and now catch little are the peacock bass. In the dry season you, no way eats them because they are all full of worms. The white piranhas decreased a lot, I used to kill them with arrows and they were very clean. When I went fishing with my wife, I got a mandubé (carnivorous fish of the genus Ageneiosus) and when I opened its tripe it was full of worms and we had to throw it away.

Researcher asked: Have you and the community decreased or stopped eating fish due to parasites?

Interviewee 4: It really decreased, because in the past I used to catch fish that didn't have worms, but now fish have a lot of worms. People used to eat some of them and now they don't eat because of the worms. Nobody buys peacocks and traíras because of the worms. People buy more piau, which is now without worms. However, there was piau that had worms in the belly, but without getting into the skin, but I think there will be later on. And that affects sales of peacock bass: nobody wants to buy it because of the worms. I sell pacu more because it eats fruits; but in a while they will also have worms as even in fruits, we may find worms.

Interviewee 5: I believe so, when I talk to my brother-in-law, he says he is disgusted to eat our fish, because of lots of worms; ox dies by the river, so people are afraid to eat fish.

Researcher asked: Why do you think fish are so full of parasites?

Interviewee 3: [...] I believe it is just like my brother said, because we were born and raised here. From about 15 years ago on, things are getting more difficult every day. I also believe that this has to do with the tree felling and a lot of poison that farmers throw on 
the land; To plant soy they throw a lot of poison, to harvest soy they throw more poison and we believe that all these poisons go to the river, so a lot of fish are dying this year. That's been happening for two years in the São Miguel River, which is almost our river, one is an affluent of the other. There was a lot of fish mortality, and in our river, there was also fish mortality. People believe that it is because of these poisons thrown in the fields and there are many streams here that throw these contaminated waters into our river. Our river is not so big here, so we can see this all happening.

Researcher asked: Are there any further considerations about the fishes, the river and the parasites that you would like to share?

Interviewee 6: Well, if they stopped using poison, I think these worms would decrease. We believe that poison and felling trees are making fish sick. There will come a time when we will not eat fish anymore, no one will want to eat a fish full of worms, people will no longer call friends to eat fish for when they try it, worms will appear and they'll say you gave them fish with worms to eat. One day we'll eat only meat.

Interviewee 6: First of all, I would like the authorities to take action on what is happening to our rivers. We had protection from IBAMA (Brazilian Institute of the Environment and Renewable Natural Resources), but now with this current government (The chieftain refers to the current Brazilian government of President Jair Bolsonaro) ... It's very sad for us who were born and raised here, it's been very difficult. But imagine how it will be in two, three years? We are sure that the children that are being born will not know the fish that we know.

Interviewee 7: What I believe that harms the fish are these farms on the banks of rivers and streams, the owners put machinery in and instead of pushing things for a place and burn it, they push everything into the water and it becomes rotten water. Then, when the flood season comes, that black, rotten water, looking like coffee, goes to the river.

\section{Discussion}


The history of the Puruborá ethnicity can be portrayed as an example of the modification of Brazilian forest spaces and the change in eating behavior, among others, due to the imbalance in the environment. In this research, several reports describe the decline of fishing in the Aperoi Village, of the Puruborá ethnicity. Among the problems mentioned are the presence of parasites in fish, and the main complaints are disgust and fear of becoming ill. In fact, some of the parasites identified in this study have zoonotic potential.

A large number (prevalence $=100 \%$ ) of Eustrongylides sp. in the musculature of jeju, traíra and tucunaré, fish that are very popular in the region. This parasite has been reported in several parts of the world, in Europe ${ }^{13}$, in $\mathrm{Asia}^{14}$ and in the Americas ${ }^{15,16}$.

Larvae of Eustrongylides sp. have been described mainly in traíra and jeju in several states in northern Brazil ${ }^{8,15-18}$.

In the literature, there are records of infection in humans and the Center for Disease Control (CDC) in the United States of America (USA) has warned of these possible zoonoses since $1982^{19}$. According to the Brazilian Regulation for Industrial and Sanitary Inspection of Products of Animal Origin - RIISPOA ${ }^{3}$, fish with endoparasites in the muscle are inappropriate for human consumption, especially when they are raw. Also, the US Food and Drug Administration (FDA) Agency warns that all fish products that are not cooked or processed at temperatures less than $60^{\circ}$ centigrade should be frozen at $-35^{\circ} \mathrm{C}$ for more than $15 \mathrm{~h}$, or at $-23^{\circ} \mathrm{C}$ for a minimum period of 7 days ${ }^{20}$.

However, it is common to consume raw fish fillet with lemon and salt during fishing ${ }^{15}$, not only by indigenous people and riverine people, but by sport fishing (personal communication).

The presence of Eustrongylides sp. in the musculature of the fish it gives a disgusting aspect, due to the large size of the larvae, reddish color and quantity found (as in the present study). It is important to emphasize that when fish are low (of parasites) they remove and ingest the meat (narrative of the interviewees). This highlights the importance of health education to the population regarding the risks of eating raw or undercooked fish. In reports of human infection, it was possible to observe that the larvae penetrate the digestive tract wall, causing perforation and severe pain $^{21}$.

In addition, Contracaecum sp., a parasite of the Anisakidae family, also has zoonotic potential and has been frequently described in native fish in Brazil ${ }^{22}$, and generally in co-infection with Eustrongylides ${ }^{23}$. There are no reports of parasitized 
humans in Brazil; however, literature reveals them in other countries such as South Korea $^{24}$, Australia ${ }^{25}$ and Japan ${ }^{14}$. We must add that descriptions of infections with Contracaecum larvae were of severe and painful condition in humans ${ }^{26}$.

There has been no epidemiology work carried out at the Aperoi Village to identify possible cycles of Eustrongylides and Contracaecum within the human community yet. Accordingly, no case of illness has been reported without identifying the primary cause. However, as the signs of such parasitism are not specific, it can be inferred that if infection occurs in this population, it may go unnoticed. Another important point to make is that, due to the unpleasant aspect of parasites in the fish meat, it turns to be disagreeable for consumption, consequently reducing its possibility and therefore, of infection.

Another parasite identified in this study was Ithyoclinostomum sp., which is a digenetic trematode, and has no reports of zoonotic potential, but that the presence of cysts containing the metacercariae of this parasite causes disgust ${ }^{27}$. This parasite has been found from north to south of Brazil ${ }^{28,29}$ and studies on the parasite-host relationship need to be conducted in order to understand the role of each host within the epidemiological cycle as well as the action of the parasite on the performance of the host.

The parasite Neoechinorhynchus buttnerae, Acanthocephala, which is located in the intestine of fish does not have zoonotic potential; however, it causes spoliation and in high parasitic loads can cause ulcerations, due to the penetration of the proboscis in the intestinal mucosa, and subsequent necrosis of the intestinal epithelium, reflecting the lack of development, appetite, and finally death ${ }^{22}$.

In Brazil, reports of human infection by parasites of native fish are scarce and attention to the health of indigenous people and the environment in which they live is poorly disclosed. It is well known that the environment, environmentalists and indigenous peoples are being severely threatened by the current Brazilian Federal Government. President Jair Bolsonaro publicly defends the opening of indigenous lands to miners and farmers, even if it increases deforestation rates in the country ${ }^{30}$. In 2019 , during the development of this research, there were several reports by the chief Hozana Puruborá of coercion and even of an attempt on her life, since she is an activist for indigenous rights, recognition of the Puruborá people and demarcation of their lands (personal communication).

The health of the indigenous people is closely linked to the health of the 
environment; therefore, the use of One Health is fundamental when analyzing populations that are culturally linked to the environment and primarily depend on natural resources for their livelihood. It would also be fundamental to identify at which points of the eco-epidemiological chain of zoonotic parasites are out of balance and try to mitigate and prevent disease outbreaks. Indeed, we are aware that about $75 \%$ of human diseases emerging in recent years were caused by pathogens from animals ${ }^{31}$. The use of pesticides and the deforestation of riverbanks put at risk the diversity of fauna, which serves as food for indigenous peoples ${ }^{32,33}$.

This fact was reported several times by the interviewees in this study, who observed that deforestation on the banks of the rivers around the village, the low water quality and the increase in fish parasites in the last ten years, have consequently forced them to choose another source of animal protein.

The indigenous peoples are called native peoples and are the guardians of Brazilian forests. Their defense, as well as that of their rights and health, is a responsibility of all Brazilians, and in general, of all countries in the world. Indeed, to preserve the health of the planet is to preserve human life. Thus, awareness of all the population and access to disease prevention information to indigenous peoples minimizes the risk of infections.

\section{Methods}

\section{Ethics and procedures}

This study was approved by the methods involving humans' subjects and were performed in accordance with relevant guidelines and criteria according to Research Ethics Committee (CEP) number 2689.242 of the Federal University of Rondônia. All participants from the indigenous community, are majority of age, agreed to the Terms of Free and Informed Consent (TCLE) and agreed that their answers are published. Informed consent was obtained from all the subjects and the study was performed in accordance with relevant guidelines. All fishes used in this study were handled in accordance with the Ethics Committee on the Use of Animals - CEUA, number 005/2018, approved by the Federal University of Rondônia. All analyzes performed with fish were in accordance with ARRIVE guidelines (https://journals.plos.org/plosbiology/article?id=10.1371/journal.pbio.3000411), and regulations of this committee, and by Chico Mendes Institute of Biodiversity 
Conservation (ICMBIo), number 63086 (https://www.gov.br/icmbio/ptbr/servicos/autorizacao-para-licenciamento-1) for the study of fished native specimens.

\section{Data collection location and sampling}

The collections of native fish were carried out in the Manoel Correia and Caio Espínola Rivers, which border the Aperoi Village, located in the municipality of Seringueiras, state of Rondônia, in the western Amazon of Brazil.

Four members of the indigenous community collected the fish in October 2019 and January 2020, according to traditional customs (nets, meshes of varying sizes, fishing rod and arrow), at four different points in the Manoel Correia and Caio Spinola Rivers: point 01 : S $20^{\circ} 27.261^{\prime}, \mathrm{W} 061^{\circ} 43.979^{\prime}$ elevation $415 \mathrm{~m}$; point 02 : S $11^{\circ} 56^{\prime} 24,180^{\prime \prime}$, $\mathrm{W} 063^{\circ} 15^{\prime} 41.0440^{\prime \prime}$ elevation $166 \mathrm{~m}$; point 03: S $11^{\circ} 55.965^{\prime}$, W $063^{\circ} 15.2966^{\prime}$ elevation $500 \mathrm{~m}$; and point $04: \mathrm{S} 11^{\circ} 46,302$ ', W $061^{\circ} 40,322^{\prime}$ elevation $390 \mathrm{~m}$.

Once the fish were collected, they were packed individually by the researchers in plastic bags identified with the date and place of collection and placed in isothermal boxes with ice for transportation (under $8.0^{\circ} \mathrm{C}$ ), for $148.8 \mathrm{~km}$, until the Laboratory of Parasitology, Entomology and Molecular Biology focused on One Health (LAPEMSU) at the Federal University of Rondônia, campus Rolim de Moura.

A number of 21 fish were collected in the dry period and 15 in the rainy season, totaling 36 specimens. The fish were weighed, measured (Table 2) and necropsied. For parasitic analysis, the organs were separated and observed under a stereomicroscope, namely: eyes, gills, intestines, liver, spleen, swimming vesicle and skeletal musculature.

The digestive tract was separated into portions and its contents were washed with $0.9 \%$ saline solution for analysis under a stereomicroscope to collect the parasites.

The nematode helminths, larvae and cysts were conditioned in $70 \%$ alcohol and the Acanthocephali were fixed in 5\% hot formalin to distend the proboscis. The identification of the parasites was based on specific bibliographic consultation according to the findings and the methodologies described by Thatcher ${ }^{34}$, Martins ${ }^{35}$ and Eiras et al. ${ }^{36}$.

Table 2. Fish species collected in Manoel Correia and Caio Espínola rivers, municipality of Seringueiras, state of Rondônia, Brazil. 


\begin{tabular}{|c|c|c|c|c|c|}
\hline Sample & Point & Scientific name & Common name & Length (cm) & Weight (g) \\
\hline 1 & 4 & Hoplerythrinus sp. & Jeju & 29 & 301 \\
\hline 2 & 4 & Hoplerythrinus sp. & Jeju & 28 & 255 \\
\hline 3 & 4 & Hoplerythrinus sp. & Jeju & 25 & 192 \\
\hline 4 & 4 & Hoplerythrinus sp. & Jeju & 25 & 195 \\
\hline 5 & 4 & Hoplerythrinus sp. & Jeju & 30 & 289 \\
\hline 6 & 4 & Hoplerythrinus sp. & Jeju & 27 & 210 \\
\hline 7 & 4 & Hoplerythrinus sp. & Jeju & 30 & 346 \\
\hline 8 & 4 & Hoplerythrinus sp. & Jeju & 31 & 340 \\
\hline 9 & 4 & Hoplerythrinus sp. & Jeju & 29 & 313 \\
\hline 10 & 4 & Hoplerythrinus sp. & Jeju & 21 & 123 \\
\hline 11 & 4 & Hoplerythrinus sp. & Jeju & 25 & 196 \\
\hline 12 & 4 & Hoplerythrinus sp. & Jeju & 30 & 227 \\
\hline 13 & 4 & Hoplerythrinus sp. & Jeju & 22 & 119 \\
\hline 14 & 4 & Hoplerythrinus sp. & Jeju & 29 & 294 \\
\hline 15 & 3 & Hoplerythrinus sp. & Jeju & 24 & 119 \\
\hline 16 & 4 & Hoplerythrinus sp. & Jeju & 27 & 245 \\
\hline 17 & 1 & Hoplias sp. & Traíra & 30 & 298 \\
\hline 18 & 3 & Hoplias sp. & Traíra & 31 & 388 \\
\hline 19 & 3 & Hoplias sp. & Traíra & 33 & 407 \\
\hline 20 & 3 & Hoplias sp. & Traíra & 25 & 144 \\
\hline 21 & 1 & Hoplias sp. & Traíra & 36 & 480 \\
\hline 22 & 3 & Hoplias sp. & Traíra & 28 & 184 \\
\hline 23 & 1 & Hoplias sp. & Traíra & 31 & 311 \\
\hline 24 & 3 & Hoplias sp. & Traíra & 32 & 317 \\
\hline 25 & 1 & Hoplias sp. & Traíra & 35 & 439 \\
\hline 26 & 2 & Hoplias sp. & Traíra & 20 & 77 \\
\hline 27 & 1 & Hoplias sp. & Traíra & 25 & 124 \\
\hline 28 & 3 & Hoplias sp. & Traíra & 35 & 423 \\
\hline 29 & 2 & Hoplias sp. & Traíra & 31 & 296 \\
\hline 30 & 1 & Hoplias sp. & Traíra & 33 & 293 \\
\hline 31 & 2 & Hoplias sp. & Traíra & 32 & 325 \\
\hline
\end{tabular}




\begin{tabular}{|l|l|l|l|l|l|}
\hline 32 & 2 & Hoplias $\mathrm{sp}$. & Traíra & 34 & 331 \\
\hline 33 & 2 & Hoplias $\mathrm{sp}$. & Traíra & 30 & 248 \\
\hline 34 & 1 & Cichla $\mathrm{sp}$ & Tucunaré & 35 & 582 \\
\hline 35 & 1 & Cichla $\mathrm{sp}$ & Tucunaré & 31 & 491 \\
\hline 36 & 1 & Pimelodus $\mathrm{sp}$. & Mandim & 30 & 130 \\
\hline
\end{tabular}

\section{Interviews with Puruborá indigenous people in Aperoi Village}

We developed this investigation according to the research precepts described by $\mathrm{Gil}^{37}$, as an exploratory study based on interviews. The researcher, also belonging to the Puruborá ethnic group, personally conducted six interviews with seven residents of Aperoi village (one of the interviews was conducted with two people: interviewee 1 and her brother interviewee 2 . The names of the five remaining interviewees are: interviewee 3 (husband of interviewee 1), interviewee 4, interviewee 5, interviewee 6 and interviewee 7. The interviews were recorded in audio and then transcribed. The questionnaire presented five questions previously planned and structured and applied in the following order:

$1^{\circ}$ ) Could you please tell me how the fishes and the Manoel Correia and Caio Espínola rivers were like about ten years ago?

$2^{\circ}$ ) Do you believe there has been a great decrease in fish populations in the Manoel Correia River? And if so, in which species did you notice the greatest decreases and presence of parasites?

$3^{\circ}$ ) Have you and the community decreased or stopped eating fish due to parasites?

$4^{\circ}$ ) Why do you think fish are so full of parasites?

$5^{\circ}$ ) Are there any further considerations about the fishes, the river and the parasites that you would like to share?

In conclusions, the circulation of parasites with zoonotic potential was identified in fish native to the Manoel Correia and Caio Espínola rivers, which border the Aperoi Village, in the Western Amazon of Brazil.

The Puruborá People's helplessness was verified regarding their inquiries about the environmental imbalance, which causes loss of fish diversity and, consequently, damage to their culture and customs. And above all, from the exposure of the indigenous people of Aperoi Village to parasitic infections due to the prevalence of zoonotic parasites in native fish used as a source of animal protein in their diet. 


\section{References}

1. Camargo, A. A., Oliveira, M. R. M., Renosto, R. V., Vieira, C. M. Promoção e avaliação da atitude de vigilância nutricional na atenção básica à saúde de municípios das bacias Piracicaba-Capivari. SAN. 17(2), 2639. DOI: https://doi.org/10.20396/san.v17i2.8634790 (2010).

2. Santos, C. A. M. L. Doenças transmitidas por pescado no Brasil. Rev. Bras. Med. Vet. 32(4), 234-41 (2010).

3. Brasil. Surtos de doenças transmitidas por alimentos no Brasil. Informe 2018. 2018. [cited 2021 Jun 12]. https://portalarquivos2.saude.gov.br/images/pdf/2019/fevereiro/15/Apresenta----o-

Surtos-DTA---Fevereiro-2019.pdf. Accessed 12 June 2021.

4. Santos, C. A. M. L. Doenças parasitárias associadas ao consumo de pescado no Brasil: incidência e epidemiologia. Hig. Aliment. 31, 65-71 (2017).

5. Martins, M. L., Moraes, F. R., Fujimoto, R. Y., Onaka, E. M., Nomura, D. T. et al. Parasitic Infections in cultivated freshwater fishes a survey of diagnosticated cases from 1993 to 1998. Rev. Bras. Med. Vet. 9(1), 23-28 (2000).

6. Santos, C. A. B., Alves, R. R. N. Ethnoichthyology of the Indigenous Truká People, Northeast Brazil. J. Ethnobiol. Ethnomed. 12(1), 1-10. DOI: https://doi.org/10.1186/s13002-015-0076-5 (2016).

7. Souza, M. M. O., Pessôa, V. L. S. The formation process of the territory of Rondônia revisited: from colonial times to the military coup d'etat of 1964. Acta Geogr. 4(8), 143 160. DOI: https://doi.org/10.5654/actageo2010.0408.0011 (2010).

8. Oliveira, A. D., Zibetti, M. L. T. E a resistência de um povo indígena da amazônia. Espaço Ameríndio. 10(1), 103-44 (2016).

9. Barboza, J. J. Puruborá: narrativas de um povo ressurgido na Amazônia brasileira. 2012 [cited 2021 June 21]. https://www.encontro2012.historiaoral.org.br/resources/anais/3/1339991713_ARQUI VO_PuruboraNarrativasdeumPovoRessurgidonaAmazonia.pdf 10. Menezes, T. R., Galucio, A.V., Velden, F. F. V. Povos indígenas em Rondônia. 2021 [cited 2021 May 26]. https://pib.socioambiental.org/pt/Povo:Purubor\%C3\%A1 
11. Montanha, G. O., Barboza, J. J., Oliveira, A. D. Puruborá: myths of a indigenous people resurgent in Amazonia. Tellus. 27, 151-174 (2014).

12. Marcogliese, D. J. Food webs and biodiversity: are parasites the missing link? $J$. Parasitol. 89(3), 106-13 (2003).

13. Branciari, R., Branciari, R., Ranucci, D., Miraglia, D., Valiani A. et al. Occurrence of Parasites of the Genus Eustrongylides spp. (Nematoda: Dioctophymatidae) in Fish Caught in Trasimeno Lake, Italy. Ital J Food Saf. 5(4), 6130. DOI: https://doi.org/

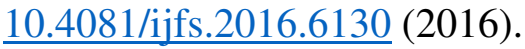

14. Nagasawa, K. The biology of Contracaecum osculatum Sensu Lato and $C$. osculatum A (Nematoda: Anisakidae) in Japanese Waters: A Review. Biosphere Sci. 51:61-69. DOI: https://doi.org/10.15027/34527 (2012).

15. Meneguetti, D. U. O., Laray, M. P. O., Camargo, L. M. A. Primeiro relato de larvas de Eustrongylides sp. (Nematoda: Dioctophymatidae) em Hoplias malabaricus (Characiformes: Erythrinidae) no estado de Rondônia, Amazônia Ocidental, Brasil. Rev Pan-Amaz Saude. 4(3), 55-58. DOI: https://doi.org/10.5123/s2176$\underline{62232013000300008}$ (2013).

16. Guagliardo, S., Viozzi, G., Brugnim, N. Pathology Associated with Larval Eustrongylides sp. (Nematoda: Dioctophymatoidea) infection in Galaxias maculatus (Actinopterygii: Galaxiidae) from Patagonia, Argentina. Int J Parasito: Parasites Wildl. 10, 113-116. DOI: https://doi.org/10.1016/j.ijppaw.2019.08.004 (2019).

17. Alcântara, N. M., Tavares-Dias, M. Structure of the parasites communities in two Erythrinidae fish from Amazon river system (Brazil). Rev. Bras. Parasitol. Vet. 24(2), 183-90. DOI: https://doi.org/10.1590/s1984-29612015039 (2015).

18. Goncąlves, R. A., Oliveira, M. S. B., Neves, L. R., Tavares-Dias, M. Seasonal pattern in parasite infracommunities of Hoplerythrinus unitaeniatus and Hoplias malabaricus (Actinopterygii: Erythrinidae) from the Brazilian Amazon. Acta Parasitol. 61(1), 119-129. DOI: https://doi.org/10.1515/ap-2016-0016 (2016).

19. Eberhard, M. L., Hurwitz, H., Sun, A. M., Coletta, D. Intestinal perforation caused by larval Eustrongylides (Nematoda: Dioctophymatoidae) in New Jersey. Am J Trop Med Hyg. 40(6), 648-50. DOI: https://doi.org/10.4269/ajtmh.1989.40.648 (1989).

20. Younis, A. E., Saad, A. I., Rabei, J. M. The occurrence of Contracaecum sp. larvae 
(Nematoda: Anisakidae) in four teleostean species from Lake Nasser, Egypt: Morphological and Molecular Studies. JoBAZ. 78, 9. https://doi.org/10.1186/s41936017-0012-4 (2017).

21. FDA - Food and Drug Administration. Bad Bug Book, Foodborne Pathogenic Microorganisms and Natural Toxins. Second Edition. 2012.

22. Manrique, W. G., Figueiredo, M. A. P., Lopes, T. H. L., Domingos, L. S., Freitas, J. et al. Weight and length correlation of tambaquis endoparasitized from feefishing ponds in Rondônia, Brazil. Ars Vet. 36(2), 125-28. DOI: http://dx.doi.org/10.15361/21750106.2020v36n2p125-128 (2020).

23. Oliveira, M., Corrêa, L., Ferreira, D., Tavares-Dias, M. Larvas de nematoides de potencial zoonótico infectando peixes carnívoros do baixo rio Jari, no norte do Brasil. Biota Amazônia. 9(4), 50-52. DOI; doi:http://dx.doi.org/10.18561/21795746/biotaamazonia.v9n4p50-52 (2020).

24. Im, K. I., Shin, H. J., Kim, B. H., Moon, S. I. Gastric anisakiasis cases in Cheju-Do, Korea Republic Korean. J Parasitol. 33(3), 179-186 (1995).

25. Shamsi, S. H., Butcher, A. R. First report of human anisakidosis in Australia. Med J Aust.194(4), 199-200. DOI: https://doi.org/10.5694/ j.1326-5377.2011.tb03772.x (2011).

26. Shamsi, S., Gasser, R. B., Beveridge, I. Mutation scanning-coupled sequencing of nuclear ribosomal DNA spacers as a tool for the specific identification of different Contracaecum (nematoda: Anisakidae) larval types. Mol Cell Probes. 25(1), 13-18. DOI: https://doi.org/10.1016/j.mcp.2010.09.003 (2011).

27. Gueretz, J. S., Senger, S. B., Claus, M. P. Occurrence of Ithyoclinostomum sp. and Eustrongylides sp. parasites of Hoplias aff. malabaricus Bloch, 1794 (Characiformes: Erythrinidae) on the coast of Santa Catarina, Brazil. Braz. J. of Develop. 6(4), 2156521575. DOI: https://doi.org/10.34117/bjdv6n4-359 (2020).

28. Gallio, M., Silva, A. S., Soares, J. F., Silva, M. K., Salomão, E. L. et al. Ocorrência de metacercárias de Ithyoclinostomum dimorphum em traíras no Rio Grande do Sul, Brasil: Relato de Caso. Estud Biol. 29(68/69), 337-339. DOI: https://doi.org/10.7213/reb.v29i68/69.22789 (2007).

29. Souza, D. C., Correa, L. L., Tavares-Dias, M. Ithyoclinostomum dimorphum 
Diesing, 1850 (Digenea, Clinostomidae) in Hoplias malabaricus (Erythrinidae) with the first report of infection of the eyes. Helminthologia. 55(4), 343-49. DOI: https://doi.org/10.2478/helm-2018-0028 (2018).

30. Global Witness. ONGs internacionais emitem alerta severo para bolsonaro sobre mudança climática e direitos humanos. 2018. https://www.globalwitness.org/en/pressreleases/international-ngos-issue-stark-warning-bolsonaro/. Accessed 14 June 2021

31. WHO - World Health Organization. World Malaria Report. WHO Press. 2014. [cited 2021 Jun 09]. https://www.who.int/publications/i/item/9789241564830. Accessed 09 June 2021.

32. Rocha, D. F., Porto, M. F. S., Pacheco, T. The struggle of indigenous peoples for health in environmental conflict contexts in Brazil (1999-2014). Ciênc Saúde Colet. 24(2), 383-392. DOI: https://doi.org/10.1590/1413-81232018242.27972016 (2019).

33. Porto, M. F., Soares, W. L. Development model, pesticides, and health: a panorama of the brazilian agricultural reality and proposals for an innovative research agenda. Rev Bras Saúde Ocup. 37(125), 17-31 (2012).

34. Thatcher, V. E. Amazon Fish Parasites. Amazoniana. 11(3-4), 263-572 (1991).

35. Martins, M. L. Doenças Infecciosas e Parasitárias de Peixes. Boletim Técnico Caunesp. 1998;3, 2. ed. (Ed. Funesp), Jaboticabal, SP, Brasil, 66p.

36. Eiras. J. C., Takemoto, R. M., Pavanelli, G. C. Métodos de estudos e técnicas laboratoriais em parasitologia de peixes. 2000. $1^{\text {a }}$ ed. Maringá: Editora Universidade Estadual de Maringá. 171p.

37. Gil, A. C. Métodos e Técnicas de Pesquisa Social. Edited by Atlas S.A. 6th ed. São Paulo. 2008.

\section{Acknowledgements}

The authors are grateful for the Puruborá people.

\section{Author contributions}

M.A.P.F., G.O.M., and W.G.M. contributed equally to this work, performed, reviewed, revised, and agreed with the manuscript.

\section{Competing interests}


The authors declare no competing interests.

\section{Additional information}

Correspondence and requests for materials should be addressed to W.G.M.

\section{Ethics declarations}

This study was approved by the Research Ethics Committee (CEP) number 2689.242 of the Federal University of Rondônia for the methods involving humans' subjects and were performed in accordance with relevant guidelines and criteria according to Research Ethics Committee (CEP) number 2689.242 of the Federal University of Rondônia. 